\title{
Heikki Kujansivu
}

\section{Kertomusten luonnosta tamperelaisittain}

Mari Hatavara, Markku Lehtimäki ja Pekka Tammi (toim.): Luonnolliset ja luonnottomat kertomukset. Jälkiklassisen narratologian suuntia. Helsinki: Gaudeamus, 2010. 336 s.

"Olipa kerran on nimeni mun, vain aluksi kelpaan satuun..." lauloi Leskinen aikoinaan hyödyntäen satujen tunnettua toposta. Vaikka kyseinen kappale - nimeltään Olipa kerran - aloittaa kokoelman, jolla se ilmestyi (Dokumentti, 1981), lainatut sanat eivät kuitenkaan avaa kappaletta vaan vasta sen kertosäkeen. Itse laulu puolestaan kertoo parisuhteen kariutumisesta tai ainakin kriisistä. Laulu siis kertaa asioita vähintään kahdella tasolla, mutta syntyykö tästä kertaamisesta kertomus. Kertooko Juice laulussaan kertomuksen? Jos kertoo, niin mikä ja kuka tekee siitä sellaisen? Ensimmäinen kysymys edellyttää vastaamista jälkimmäiseen, koska laulujen sanat eivät lajina ole itsestään selvästi kertomuksia ja koska Juicen sanat eivät itsessään vielä muodosta tavanomaista kertomusta. Näin laulun sanat ja niiden kerronta nostavat esiin perustavamman kysymyksen: mikä on kertomuksen luonto ja missä se sijaitsee?

Tämä kysymys on myös artikkelikokoelman Luonnolliset ja luonnottomat kertomukset kysymyksenasettelujen taustalla. Teos on kirjallisuudentutkimuksemme Tampereen koulun voimannäyte. Sen kymmenestä kotimaisesta kirjoittajasta vain kahta (Mikko Keskinen, Henry Bacon) ei voida kytkeä suoraan Tampereen yliopiston kirjallisuusaineisiin ja/tai niissä vallitsevaan suuntaukseen. Nyt ilmestynyt teos poikkeaa osin samojen tekijöiden parin vuoden takaisesta kokoelmasta Näkökulmia kertomuksen tutkimukseen (2009) lähinnä kahdella tavalla: 1. turkulaiset tutkijat ja heidän hieman erilainen näkökulmansa on jätetty pois ja 2. teoksen lähtökohdaksi on otettu yksi teoreettinen kysymys. Molemmat ratkaisut eheyttävät kokoelmaa. Teos sopiikin hyvin oman osa-alueensa oppikirjaksi kirjallisuusaineissa. Se ei kuitenkaan ole leimallisesti oppikirja vaan artikkelikokoelma, jonka kaikki kirjoitukset ovat itsenäisiä tutkimusartikkeleita.

Yhtä lukuun ottamatta kaikki kokoelman artikkelit myös käsittelevät aihettaan varsin ansiokkaasti ja mielenkiintoisesti. Teoksen rakenteellisesti sekä sisällöllisesti parhaita artikkeleita ovat Mari Hatavaran analyysi historiallisten romaanien kerronnasta sekä Laura Karttusen artikkeli puheen suorasta esityksestä. Kokoelman hutina voidaan pitää Pekka Tammen "kertomusta vastaan” -teemaa hyödyntävää artikkelia, josta tekijä on jo aiemmin julkaissut eri versioita. Esityksestä jää lukijalle käteen lähinnä mielikuva, 
että jotain vastustetaan, mutta ei selkeästi perusteltua näkemystä siitä, mitä ja miksi saati näkemystä siitä, mitä tilalle ehdotetaan. Ehkä artikkelia voisikin lukea osin sen umpikujan ilmentäjänä, johon kertomuksen teorian uudet tuulet ovat ajaneet perinteisen strukturalistisen narratologian ja siihen perustuvan argumentoinnin.

Liki kaikki teoksen kirjoittajat edustavat taiteiden tutkimusta. Poikkeuksen muodostaa vain sosiologi Matti Hyvärinen. Ehkä tästä johtuen myös toimittajien johdannossa lupailema monitieteisyys (8) jää varsin ohueksi ja muiden tieteenalojen kysymyksiä ja erityisongelmia tuodaan esiin lähinnä taideaineiden näkökulmasta. Teoksen ensisijainen yleisö koostuu kiistatta kirjallisuudesta ja elokuvasta sekä niiden tutkimuksesta kiinnostuneista henkilöistä.

\section{Luonnolliset kertomukset ja kertomuksellinen käänne}

Käsillä olevan kokoelman alaotsikko asemoi teoksessa esitetyt näkökulmat jälkiklassiseksi narratologiaksi. Termillä viitataan strukturalistisen narratologian jälkeiseen kertomuksen teoriaan. Itse puhuisin mieluummin vain yleisesti kertomuksen teoriasta. Näin vältetään mielikuva, että strukturalistinen narratologia olisi jotenkin klassista - tai klassisempaa kuin joku muu teoria - ja että aiemmat kertomuksen teoreetikot olisivat lähes poikkeuksetta sitoutuneet strukturalistisen narratologian projektiin. Esimerkiksi luonnollisen kertomuksen käsitteeseen kiteytyvässä kertomuksen teoriassa on itse asiassa kyse sekä uusista erilaisista lähtökohdista että tukeutumisesta aiempiin tutkijoihin, joiden ajattelu ei ole leimallisesti strukturalistista. Olennaisinta kuitenkin on, että teoreettisena projektina strukturalistinen narratologia kuivui kokoon ja sen tilalle nousi muita kertomusteoreettisia näkemyksiä. Tämä tarkoittaa myös, että kokonaisvaltaisena teoreettisena näkemyksenä narratologia ei enää muodosta varteenotettavaa vaihtoehtoa uusille kertomusteoreettisille näkemyksille.

Kirjallisuudentutkimuksessa luonnollisen kertomuksen käsitteen teki tunnetuksi Monika Fludernik teoksessaan Towards a "Natural" Narratology (1996). Fludernikin "luonnollinen" narratologia ei tietenkään ole ainoa kertomuksen teorian nykysuuntaus. Se on kuitenkin niistä varmasti tunnetuin, ja Fludernikin teosta voi syystä pitää merkittävimpänä kertomuksen teorian alalla parin viime vuosikymmenen aikana julkaistuna yksittäisenä tutkimuksena. Fludernikin näkemyksen tunnettuus perustuu epäilemättä osin sen nimeämiseen narratologiaksi sekä sen esittämiseen kokonaisvaltaisena kertomuksen teoriana. Molemmilla tavoilla Fludernik esittää haasteen nimenomaan strukturalistiselle narratologialle. Hatavaran, Lehtimäen ja Tammen toimittamassa kokoelmassa on pitkälti kyse juuri tästä "luonnollisen narratologian" haasteesta. Lähes kaikki kirjoittajat kommentoivat jotenkin luonnollisen kertomuksen käsitettä, ja monet heistä myös arvioivat sen narratologialle asettamaa haastetta. Teoksen lähtökohtana toimii näin kysymys luonnollisista kertomuksista - ja siis kertomusten luonnosta. 
Fludernikin teoksen tekee tärkeäksi siinä esitetty monitahoinen, lähinnä kognitiiviseen psykologiaan ja kognitiotieteeseen pohjautuva kertomuksen teoria. Fludernikin esittämä näkemys ilmentää siten myös yleisempää kognitiotieteen synnyttämää käännettä. Esimerkiksi filosofiassa analoginen käänne näkyy hyvin siinä, miten jotkut analyyttisen kielifilosofian edustajat - esimerkiksi John Searle - ovat viime aikoina korostaneet mielen filosofian merkitystä myös kielen filosofialle. Mieli on siis korvannut kielen ensisijaisena tai perustavana tutkimuskohteena, myös silloin kun kyse on lopulta kielestä. Toisaalta Fludernikin teoria kytkeytyy myös kertomukselliseen käänteeseen laajentaessaan kertomuksen teoriassa tarkasteltavien kertomusten alaa.

Fludernik viittaa luonnollisen kertomuksen käsitteellä spontaaniin keskusteluissa tapahtuvaan kerrontaan. Käsitteen ulkopuolelle jäävät sekä kirjalliset kertomukset että konventionaaliset suullisen kertomuksen muodot. Käsite pohjautuu sosiolingvistiikkaan ja muodostaa Fludernikin teorian peruskäsitteen: historiallisen ja rakenteellisen kertomuksen perusmuodon. Kyse on ihmisen "luonnollisesta", kognitiivisesta tavasta hahmottaa kertominen ja kertomus. Käsillä olevan teoksen avaava Monika Fludernikin alun perin vuonna 2003 ilmestynyt artikkeli "Luonnollinen narratologia ja kognitiiviset parametrit" esittelee selkeästi sekä luonnollisen kertomuksen käsitteen että teorian muut perusajatukset ja vastaa samalla joihinkin teoriaan kohdistettuihin kritiikkeihin. Artikkeli tuo hyvin esiin hänen näkemyksensä perustumisen inhimilliseen kokemukseen ja ihmisen tapaan hahmottaa tästä kokemuksesta kertominen. Samalla ilmi tulevat myös näkemyksen eri ulottuvuudet ja sen kerrostuneisuus, joiden tavoitteena on esimerkiksi sisällyttää teoriaan tällaisesta perustavaksi ja tavanomaiseksi esitetystä kokemuksista kertomisesta poikkeavat tapaukset. Ne selittyvät mallissa kulttuuris-historiallisesti kehittyneinä ja opittuina konventioina, "luonnollisen" perustilanteen pohjalta tavanomaistettuina tai "luonnollistettuina" tapauksina.

Kokoelmassa Fludernikin artikkelia seuraa hänen oppilaansa ja kollegansa Jan Alberin tuore, alun perin vuonna 2009 ilmestynyt artikkeli "Mahdottomat tarinamaailmat - ja mitä niillä voi tehdä", jossa tekijä esittelee epäluonnollisen käsitteeseen pohjautuen erilaisia kertomusten mahdottomia maailmoja. Artikkelin tarkoituksena on mitä ilmeisimmin edustaa teoksen otsikossa mainittua luonnottomien kertomusten näkökulmaa. Alberin muuten mainio artikkeli keskittyy kuitenkin eri asiaan kuin Fludernik ja näin artikkelit oikeastaan puhuvat toistensa ohi, mitä voi näkökulmasta riippuen pitää hyvänä tai ongelmallisena asiana. Joka tapauksessa Fludernikin teoreettisen mallin kannalta tärkeintä on kerronta, kun taas Alber keskittyy artikkelissaan kerrottuun. Kertomusten luonnollisuuden kannalta kyse on kahdesta eri asiasta. Kerronnan luonnollisuus ei sulje pois kerrotun luonnottomuutta. Voitaisiin jopa väittää, että näiden kahden asian välillä vallitsee negatiivinen korrelaatio: mitä ihmeellisempää ja omasta elämismaailmastamme poikkeavaa maailmaa kuvataan, sitä vähemmän on 
tilaa radikaaleille kerronnallisille ratkaisuille, ja päinvastoin.

Lopulta Alber paljastuukin täysiveriseksi luonnollisen narratologian edustajaksi. Varmaan osin tästä johtuen suuri osa Alberin esimerkkikertomuksista on näytelmiä. Luonnollisen narratologian mallissa tekstilajilla tai sen suhteella esitykseen ei ole suurta merkitystä, koska kertomus syntyy osin lukijoiden luonnollistamisen seurauksena ja mallin prototyyppinä toimii suullinen kertomistilanne, johon mikä tahansa teksti voidaan periaatteessa palauttaa kuorimalla siitä historiallisesti kehittyneet kerrokset pois. Näytelmien kohteleminen valmiina kertomuksina ei kuitenkaan ole ongelmatonta.

Kokoelman kirjoittajista viime mainitun asian huomaa tarkkanäköisesti Markku Lehtimäki (287) elokuvakerronnan luonnollisuutta ja elokuvien luonnonkuvausta tarkastelevassa artikkelissaan. Muuten ja etenkin niiltä kirjoittajilta, jotka teoksessa arvioivat suoraan luonnollisen narratologian mallia, olisin toivonut enemmän tarkkaa valittujen teoreettisten esimerkkitekstien analyysia. Kertomusanalyysien kautta argumentointi kun ei aina avaa teoreettisen näkemyksen kaikkia ulottuvuuksia ja ongelmia. Tarvitaan myös itse teoreettisen tekstin analyysia.

Kognitiivisen käänteen ohella Fludernikin teoria kytkeytyy toiseen viimeaikaiseen ilmiöön: kertomukselliseen käänteeseen. Tässä käänteessä on kyse eri tieteenaloilla viime vuosina heränneestä kiinnostuksesta kertomuksiin empiirisinä aineistoina ja kertomuksen käsitteeseen erilaisten ilmiöiden hahmottamistavan kuvauksena. Käänne näkyy tässä mielessä esimerkiksi yhteiskuntatieteissä ja joillakin filosofian osa-alueilla. Fludernikin näkemyksen yhteydet käänteeseen ovat seurausta toisiinsa liittyvistä lähtökohdista ja laajennetusta kertomuksen käsitteestä. Luonnollisen narratologian pohjautuminen sosiolingvistisiin analyyseihin yhdistää näkemystä yhteiskuntatieteelliseen puheen- ja keskusteluntutkimukseen. Luonnollisten ja luonnollistettujen kertomusten käsite puolestaan kattaa paljon muutakin kuin vain kaunokirjalliset kertomukset.

Luonnollisen kertomuksen käsitteen yhteys tähän käänteeseen jää Hatavaran, Lehtimäen ja Tammen kokoelmassa kuitenkin vähälle huomiolle. Kertomuksellisen käänteen ottaa teoksessa esille oikeastaan vain Matti Hyvärinen, jolle yhteiskuntatieteilijänä asia on varmasti tutumpi kuin taiteentutkijoille. Juuri tästä syystä odotin hänen muuten kiinnostavalta ja ansiokkaalta artikkeliltaan laajempaa yhteiskunnallisen tutkimuksen kertomuksellisen käänteen kuvausta ja siihen liittyvien erityiskysymysten esittelyä ja analysointia. Nyt artikkelissa käsitellään filosofisia kertomuksellisuutta korostavia näkemyksiä, narratiivista psykologiaa, kirjallisuudenteoriaa ja kirjallisuuttakin, mutta varsinaiset kertomusta hyödyntävät sosiologiset tutkimukset sivuutetaan muutamin maininnoin. Niillä ja niissä kerätyillä kertomusaineistoilla voisi olla annettavaa myös kirjallisuudentutkimukselle. Aineistojen kertomukset poikkeavat varmasti eri tavoin kirjallisista kertomuksista, ja monien muiden laadullisten aineistojen tavoin ne johtavat useimmiten kysymykseen siitä, mitä ja mistä ne lopulta kertovat (todellisuudesta, 
kuvitelmista, ihanteista, toiveista, odotuksista, tms.) ja mihin tarpeeseen ne vastaavat. Toisaalta kertomuksellisen käänteen tarkempi hahmottaminen voisi tuoda selkeyttä kertomusten ja kertomuspuheen eroon ja samalla käänteen todelliseen laajuuteen. Kertomuspuhe kun ei vielä implikoi kertomusta sen enempää kuin innovaatiopuhe implikoi innovaation.

\section{Luonnollisuudesta ja kertomusten luonnosta}

Samuli Hägg toteaa kokoelmaan sisältyvässä tylsyyden kerrontaa ja (luku)kokemusta analysoivassa artikkelissaan (122-123), että Fludernikin luonnollisen narratologian heikko kohta on, ettei se sovellu tekstien analyysiin. Se ei toisin sanoen tarjoa tutkijalle aiemman kertomuksen teorian tavoin käsitteellisiä välineitä, joiden avulla kertomusten eri piirteitä voidaan hahmottaa. Häggin toteamus pitää kiistatta paikkansa. Voidaan kuitenkin kysyä, onko tämä edes ollut Fludernikin tarkoitus. Fludernik toki kritisoi joitain aiemman kertomuksen teorian käsitteitä ja on valmis osan niistä hylkäämäänkin. Hänen luonnollisen narratologiansa päätavoite on kuitenkin tarjota kertomuksen tutkimukselle uudenlainen teoreettinen perusta ja korjata aiempaa käsitevalikoimaa ainoastaan tämän perustan edellyttämin osin. Käytännössä luonnollinen narratologia tavoittelee toisaalta yleisinhimillistä, toisaalta historiallis-kulttuurista kertomuksen teoriaa. Tässä suhteessa sen pyrkimyksenä voi pitää viime kädessä synkronistisesta kertomuksen yleisten rakenteiden korostuksesta luopumista (mikä ei tarkoita, että se pääsisi siitä täysin eroon). Kiista, jos sellaista on, koskee siis kertomuksen teorian perustaa, ei niinkään itse kertomuksen rakenteita. Samalla siirrytään toisenlaiseen käsitykseen teoriasta ja sen tehtävistä.

Vaikka kuinka toivoisi, asetelma ei kuitenkaan ole näin selkeä. Sitä sekoittavat etenkin muutamat Fludernikin luonnollisen narratologian piirteet. Ensinnäkin teorian nimeäminen narratologiaksi johtaa miltei automaattisesti vertaamaan teoriaa (strukturalistiseen) narratologiaan, koska termi kytkeytyy juuri kyseiseen kertomusteoreettiseen projektiin. Tämä on varmasti osin myös tarkoitus, mutta koska kyse on perustaltaan ja tavoitteiltaan erilaisista teorioista, seurauksena on sekaannus. Toiseksi asetelmaa sekoittavat Fludernikin teoriaan sisältyvät valinnat ja ylilyönnit, jotka aiheuttavat todellisia ongelmia myös itse teorialle. Tässä ei ole luonnollisestikaan mahdollisuutta arvioida yksityiskohtaisesti koko teoriaa tai sen ongelmia. Käsillä oleva kokoelma tarjoaa oivan kuvan Fludernikin näkemyksestä sekä myös välineitä ongelmien hahmottamiseen. Otan esiin vain kaksi kysymystä, joista toinen on lähinnä terminologinen ja toinen liittyy kertomuksesta esitettyyn käsitykseen. Molemmat ovat kokoelman aiheen kannalta tärkeitä, mutta niitä ei kehitellä itse kokoelmassa oikein mitenkään.

Fludernikin luonnollisen narratologian kiistattomana ansiona voidaan pitää, että se palauttaa kertomuksen käsitteen inhimilliseen kokemusmaailmaan tekemällä 
kokemuksellisuudesta kertomuksen teorian yhden perustan. Näin kertomuksesta tulee filosofisestikin kiinnostava asia. Se ei jää pelkästään tekniseksi kysymykseksi. Näkemyksen kutsuminen "luonnolliseksi” sisältää kuitenkin ongelmia. "Luonto" ja siitä johdettu "luonnollinen" ovat jo sinänsä ongelmallisia käsitteitä. "Luontoa" voidaan käyttää erottamaan inhimillinen kulttuuri ja siihen sisältyvät teot ja tuotokset sitä ympäröivästä muusta ja se voi jakaa myös ihmisen kahtia luontoon kuuluvaan puoleen ja johonkin muuhun. Mutta yhtä hyvin "luonto" voi kattaa kaiken meissä ja ympärillämme olevan. Olennaisinta on, että luonnon ja muun rajaa ei voida koskaan selkeästi ja kiistattomasti vetää, mutta raja on aina olemassa. Se voidaan aina myös vetää usealla eri tavalla.

Fludernikin "luonnollisen" käsite viittaa ennen kaikkea ihmisille luonteen- tai tavanomaisiin tapoihin mieltää ja työstää kertomista ja kertomuksia. Luonnollisia kertomuksia syntyy spontaanisti ihmisten välisissä keskusteluissa kerrottuna. Rakenteistuneemmat kertomuksen muodot perustuvat tähän luonnolliseen kertomistilanteeseen ja niitä hahmotetaan sen perusteella. Niihin mahdollisesti sisältyvät tämänkaltaisessa luonnolliseksi määritetyssä tilanteessa mahdottomat rakenteet eivät kuitenkaan vielä tee niistä laadullisesti jotain muuta - luonnottomia tai epäluonnollisia, joskin luonnollisen tilanteen näkökulmasta ne näyttäytyvät juuri sellaisina. Fludernikin mallissa tämä kertomustyyppien laajentuminen ja muuttuminen selittyykin historiallisesti ikään kuin sivilisoitumisprosessiin kuuluvana kehityksenä.

Tämä voi tuntua mielekkäältä - ja monilta osin myös on sitä. Fludernikin teoriassa "luonnollinen" kuitenkin näyttelee kaksoisroolia. Se sekä vahvistaa että kiistää samalla kertaa oman "luonnollisuutensa" ja vieläpä eri tavoin. Luonnolliseksi määritetty tilanne ei itse asiassa ole lainkaan "luonnollinen", vaan jo teoreettinen konstruktio oli kyse sitten diskurssianalyyttisestä käsitteestä tai kognitiivisen psykologian luonnolliseksi esittämästä mieltämisen tavasta. Luonnolliseksi nimeäminen tekee siitä kuitenkin väistämättä "luonnollisemman" tai alkuperäisemmän ja perustavamman kuin muut tilanteet. Sama pätee luonnollisiin kertomuksiin. Ne sekä ovat että eivät ole luonnollisempia kuin muut kertomukset. Fludernik esittääkin luonnollisen olevan sekä annettu että konstruoitu. Tästä seuraa kuitenkin ongelma. Jos ihmisillä on jokin kognitiivisesti luontainen (annettu) tapa hahmottaa kokemuksia ja niistä kertomista, tämä tarkoittaa, että myös jokin tapa kertoa eli jokin kertomuksen muoto on ihmisille luonnollinen, so. ratkaisevasti luonnollisempi kuin muut. Jos taas kaikki kertomukset ovat aina rakenteistuneita eli yhtä lailla institutionalisoituneita, tämä tarkoittaa, että mikään niistä ei ole ratkaisevasti luonnollisempi kuin jokin muu.

Ongelma on siten pitkälti, muttei yksinomaan terminologinen. Se olisi ainakin osin ratkennut käsitettä vaihtamalla. Toisaalta juuri kyseinen käsite on Fludernikille hyödyllinen: luonnollisesta puhuminen mahdollistaa pelaamisen kaksilla korteilla. 
Hänen tavastaan käyttää käsitettä seuraa myös, että esimerkiksi käsillä olevan kokoelman nimi voidaan lukea sekä konjunktiivisesti että disjunktiivisesti. Molemmat lukutavat ovat mahdollisia, koska näkemykseen sisältyy kaksi näkökulmaa, joista toisessa erottelu voidaan tehdä ja toisessa ei, mutta joiden välillä ei tarvitse valita. On siis olemassa luonnollisia ja luonnottomia (tai vähemmän luonnollisia) kertomuksia, ja ne kaikki ovat luonnottomia. Ainakin itsestäni tuntuisi kuitenkin luonnollisemmalta keskittyä nimenomaan rajanvedon ongelmallisuuteen ja sanoa, että kertomukset ovat luonnollisesti aina luonnollisia ja luonnottomia. Kokoelman nimi olisi siten luettavissa vain konjunktiivisesti.

Toinen kysymys koskee Fludernikin pyrkimystä hahmottaa kertomuksen luonne uudella tavalla. Fludernikin mukaan kertomusta kyllä märittävät erilaiset tekstuaaliset ja kontekstuaaliset piirteet, mutta ne - esimerkiksi juonellinen tarina tai tekstin nimeäminen kertomukseksi - eivät kuitenkaan vielä tee siitä kertomusta. Niiden sijaan diskurssista tai tekstistä tekee kertomuksen lukijan kertomuksellistamisen akti, lukijan tulkintaan sisältyvä ja siinä tuotettu tapa hahmottaa teksti kertomuksena. Ajatus nostaa tekstin sijaan etualalle (lukijan) mielen, ja sen hyvinä puolina voidaankin pitää lukijan aktiivisen roolin sekä tietynlaisen prosessuaalisuuden korostamista.

Tähän Fludernikin yritykseen hahmottaa uudelleen kertomuksen luonne paikantamalla se lukijan toimintaan sisältyy kuitenkin myös ongelmia. Yksi niistä liittyy näkemyksen osittaisuuteen. Vaikka hyväksyttäisiin Fludernikin kognitivistiset lähtökohdat, voidaan kysyä, mihin yksinomaan lukijan ratkaiseva rooli perustuu. Jos kertomuksen luonnetta etsitään tekstin ulkopuolelta ja sen argumentoidaan sisältyvän ihmisen tapaan hahmottaa mitä tahansa tekstuaalista, myös muut tekstiin kytkeytyvät ulkoiset toimijat tulisi huomioida. Fludernikin näkemyksestä kuitenkin puuttuu kokonaan esimerkiksi tekijä, jolla ihmisenä on lukijan tavoin mieli. Tekijä on tietenkin myös lukija, mutta häntä ei voi samastaa lukijaan, koska heidän suhteensa tekstiin tai diskurssiin on erilainen. Tekijän teko on eri teko kuin lukijan teko. Tämän eron huomiotta jättämisestä seuraa näitä rooleja ja tekoja koskeva sekaannus.

Fludernikilla siis vasta lukija viimeistelee kirjallisesti tai suullisesti esitetyn muokkaamalla siitä mielessään juonellisen kertomuksen ja siten tekee tekijän diskurssista kertomuksen. Lukija on tekijä jo lukiessaan. Mutta jos asia on näin, mitä tekijä sitten teki esittäessään sen. Eikö hän kertonutkaan kertomusta? Lieneekin selvää, että pelkkä luetun tulkinnallinen jäsentäminen ei vielä tee kertomusta tai ole sellainen. Lukija voi tietenkin esittää lukemansa pohjalta kertomuksen, mutta se on jo toinen lukijalle kerrottuun perustuva kertomus, jonka esittäminen tekee lukijasta tekijän. Kertomus voi siten hyvin rakentua mielessä, mutta tämä mieli ei ole lukijan vaan tekijän "mieli", vaikka kyse olisi samasta henkilöstä. Toisaalta pelkkä mielessä rakentuminen ei riitä. Kertomus pitää myös esittää. Vasta kertominen tuottaa kertomuksen. 
Sama asia voidaan pukea toisiin sanoihin, jolloin ongelma näyttäytyy eri kulmasta. Luonnollisessa narratologiassa kertomus syntyy siis kertomuksellistamisen aktissa. Tämä tarkoittaa samalla, että kaikki luetut tekstit - ja lopulta mikä tahansa ilmiö - voidaan periaatteessa kertomuksellistaa, vaikka toisten kohdalla se on vaikeampaa kuin toisten. Tekijän näkökulmasta asia on tietenkin ilmeinen. Kertomuksia voidaan kertoa melkein mistä tahansa. Koska kyse on kuitenkin nimenomaan lukijan mielessä tapahtuvasta kertomuksellistamisesta, Fludernik joutuu sitoutumaan käsitykseen, jossa kaikki nämä tekstit ja ilmiöt kertomuksellistettuina ovat jo kertomuksia tai käyvät sellaisista. Tämä vaikuttaa värältä. Ajatus ei vastaa oikein millään tavoin sitä, mitä kertomuksella on totuttu ymmärtämään, vaikka se säilyttää kaikki kertomuksen perinteiset piirteet. Nyt ne on vain sijoitettu tekstin sijaan lukijan mieleen. Tämän seurauksena kertomuksen käsite kuitenkin laajenee liikaa. Sitä ei viime kädessä rajoita mikään (mielen ulkopuolella). Ongelma johtuu taas sekaannuksesta, jossa kertominen ja kertomuksellistaminen näyttäytyvät samana tekona. Sitä ne eivät kuitenkaan ole. Jonkin kertomuksena hahmottamisen muuttuminen kertomukseksi edellyttää edelleen, että se kerrotaan. On kuitenkin ilmeistä, että tämä kertominen ei tee kertomuksellistetusta ilmiöstä tai tekstistä itsestään kertomusta - jos se ei jo ollut sellainen.

Lukeminen on eri asia kuin kertominen ja jonkin kertomuksellistaminen on eri asia kuin valmis kertomus huolimatta siitä, sitoutuuko kognitivistiseen näkökulmaan vai ei. Niiden sekoittamisen voi puolestaan ajatella johtuvan puutteellisesta mielen (kognition) ja kielen (kertomusten) suhteen sekä niiden intensioon ja ekstensioon liittyvien kysymysten jäsentämisestä.

Nämä Fludernikin luonnollisen narratologian ongelmat kytkeytyvät kiinnostavalla tavalla kertomukselliseen käänteeseen. Käänteestä puhuminen seuraa tietenkin todellista, aiempaa laajempaa kiinnostusta kertomuksen käsitteeseen ja kertomuksiin esimerkiksi aineistoina. Toisaalta ilmiöön liittyy myös paljon sellaista, millä on vain epäsuora yhteys kertomuksiin. On helppo nähdä, kuinka Fludernikin näkemys johtaa suoraan kertomuksen alan laajenemiseen. Kokoelmassa käytännön esimerkin tästä tarjoaa Jan Alberin tapa kohdella näytelmiä ongelmattomasti kertomuksina. Tässä suhteessa luonnollisen narratologian kertomuksen käsitettä voi pitää joidenkin kertomuksellisen käänteen ongelmallisten piirteiden teoreettisena vastineena. Muun muassa tästä syystä kertomukset on nykytilanteessa syytä erottaa esimerkiksi asioiden hahmottamisesta kertomuksellisina sekä kertomuspuheesta. Asioiden hahmottaminen kertomuksellisina tarkoittaa niiden jäsentämistä ikään kuin ne olisivat kertomuksia ja korostaa mahdollisuutta kertoa ne sellaisina. Kertomuspuhe puolestaan tarkoittaa kertomuksen käsitettä metaforisesti hyödyntävää puhetta, jossa viitteet kertomuksiin liittyvät usein muihin tarkoitusperiin kuin kertomuksiin itseensä, ja siten myös metafora on vaihdettavissa johonkin toiseen. Hyviä esimerkkejä tästä (muoti)ilmiöstä tarjoaa 
Christian Salmon teoksessaan Storytelling (2007). Näiden erottelujen tarkemman kehittelyn paikka on kuitenkin muualla.

\section{Sen pituinen se...}

Palataan vielä lyhyesti asian ytimeen eli kertomuksen luontoon. Annetaan Leskisen kuitenkin jo levätä rauhassa ja jätetään avoimeksi, mikä tai kuka kelpaa myös satuun ja sen loppuun. Kysytään sen sijaan, kertoiko tämä teksti kertomuksen. Oma vastaukseni on: ei. Teksti voidaan toki kertomuksellistaa, mutta silloin siihen täytyy ympätä erilaisia (tamperelaisia) toimijoita ja tapahtumia. Kun näin tehdään, kyse ei ole kuitenkaan enää tästä tekstistä kertomuksena, vaan jostain muusta: tätä tekstiä koskevasta kertomuksesta, sikäli kuin se kerrotaan. Kertomuksen luonto muodostuu näin aina kertomisen prosessissa ja koostuu siitä. 